SLOVO, sv. 68 (2018), 51-71, Zagreb 2018.

Марияна ЦИБРАНСКА-КОСТОВА

UDK 821.163.2’04

$821.163 .41^{\prime} 04$

271

Институт за български език - БАН

София

m.tsibranska@gmail.com

Izvorni znanstveni članak

Primljen: 29. travnja 2018.

Prihvaćen: 29. studenoga 2018.

\title{
ЕКСЦЕРПТИТЕ ОТ ПАНОПЛИЯ ДОГМАТИКА В ЗАГРЕБСКИЯ СБОРНИК НА ВЛАДИСЛАВ ГРАМАТИК ОТ 1469 г.
}

Статията се фокусира върху преводните ексцерпти от Паноплия Догматика на Евтимий Зигавин, XII в., в сборника на Владислав Граматик от 1469 г., известен още като Загребски сборник (HAZU, III a 47, 740r-752r). Става выпрос за следните две текстови единици: 1. Въвеждащ енкомион, стихове за похвала към император Алексий Комнин (1081-1118), съставен от самия Евтимий Зигавин; 2. Предговора, или Пролога, към труда на Зигавин. И двата текста се публикуват наборно като комплекс за първи път. Авторката формулира хипотеза защо тези текстове са включени в сборника и в какви текстови връзки се намират с аналогичните текстове в преписите на пълния славянски превод на Първата книга от Паноплия Догматика, а именно: HM.SMS 186 - препис от XVI от Хилендарския манастир на Атон; III с 16 - препис от колекцията на А. Миханович в HAZU, също датиран от XVI в. Сравнението между тях позволява да се поддържа мнението, че Владислав Граматик е бил добре запознат с антиеретическия компендиум на Зигавин и че целенасочено е избрал такива текстови единици, които възпроизвеждат важни аспекти от универсалния модел на средновековното православно общество, симбиозата между политическата власт, литературата и културата, между владетеля и Православието. И двата текста от сборника от 1469 г. са тематически свързани с основната идея на пространната преписваческа бележка на дяк Владислав в края на ръкопис III a 47, известна още като Послание на книжовника към Димитър Кантакузин, поръчител на сборника. Друг извод от езиково естество е този, че двата ексцерпта от Паноплията, преписани от Владислав Граматик, са в различна текстова редакция в сравнение с поместеното в пълните славянски преписи на Паноплията. Авторката посочва важността на ексцерптите в Загребския сборник за възстановяване на археографското досие на Паноплия Догматика в славянската традиция, както и за отговорите на редица дискусионни въпроси къде, кога и от кого е осъществен нейният пълен славянски превод. Тясната връзка с ортодоксията и ортопраксията на атонското монашеско братство е твърде вероятният двигател за продължителното разпространение и преписване на този фундаментален текст, особено след 1453 г., когато Православието, повече от всякога, се нуждае от догматическите основи на своята идентичност.

Ключови думи : енкомиони, Паноплия Догматика, старославянска традиция, Владислав Граматик, Атон 


\section{1. ВЪВЕДЕНИЕ}

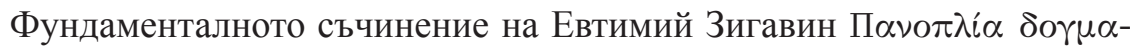
$\tau \iota x \dot{~(н а т а т ь к ~ П Д) ~ е ~ в и з а н т и и ̆ с к а ~ а н т и е р е т и ч е с к а ~ е н ц и к л о п е д и я ~ в ~ д в е ~ к н и-~}$ ги и общо 28 титула срещу всички известни на автора ереси от Симеон Влъхва до сарацините, наречени още измаилтяни, агаряни, мохамедани ( $P G$ 9-1359; WICKERT 1910; BARMIN 2008: 448-450; BERKE 2011; RIGO 19-32; ANGOLD 2000: 45-72; MILADINOVA 2010; HAMILTON 1998: 180-195). Съчинението, в голяма степен компилативно и с множество позовавания на светите отци на Църквата, възниква по времето и с порьчителството на византийския император Алексий I Комнин (1081-1118) и е завършено като зрял труд на известния монах ересиолог между 1104-1118 г. Неговата славянска рецепция поставя редица спорни въпроси и има все още неясна съдба. Съвременната равносметка от археографското досие на този обемен и сложен догматически текст в славянската традиция е следната.

1. Старославянският превод на Първата книга от първи до 11-и титул включително е известен само по два преписа: ръкопис HM.SMS 186 от сбирката на Хилендарския манастир на Атон и ръкопис III c 16 от колекцията на Антон Миханович в бившия Архив на Югославската академия на науката и изкуствата в Загреб (Архив ЈАЗУ), понастоящем Архив на Хърватската Академия на науките (XАЗУ), и двата датирани от средата на XVI в. (MOŠIN 1955: 111-115; BOGDANOVIĆ 1978: 104; MATEJIC; THOMAS 1992: 391; IVANOVA 1987). Ръкописите влизат в научно обращение с езиковата характеристика на представители на сръбската редакция на старославянски. ${ }^{1}$

2. Втората книга на Паноплията е запазена единствено: в ръкопис BAR Ms.slav. 296 от пьрвата четвърт на XV (1410-1420), който започва с 12-и титул и завършва с титула за масалианите на л. $330 б$, но без неговия край (в гръцкия оригинал номериран като 26-и, но в славянския номерацията е променена и той е 22-и), а титульт за богомилите и фрагмент от последния титул за сарацините се откриват в ръкопис от сбирката на Одеската държавна на-

1 Тази особеност на преписите бе изтькната от един от анонимните рецензенти, на когото изразявам благодарност. Езиковата природа на превода на ПД подлежи на доказване и уточняване, доколкото до момента не са правени специализирани изследвания върху морфологията, синтаксиса и лексиката. Правописът на преписите от Първата книга носи следите на безюсовата норма, свързана със сръбската редакция на старославянски. 
учна библиотека ОГНБ 1/108 с приблизително сьщата датировка от края на XIV - първата четвърт на XV в. (ÂCIMIRSKIJ 1905: 445-446; VASIL̂EV; GROZDANOVIĆ; J̌OVANOVIĆ 1980: 56; PANAITESCU 1959: 395-396 MIRCEA 2005: 62; TRIFUNOVIĆ 1979: 184, 230-232). ${ }^{2}$ »Букурещката« и »одеската« част от Вmoрата книга на ПД обикновено се разглеждат като две части на едно книжно тяло с един и същ преписвач, за когото са изказвани различни предположения, но тъй като до момента специализирани кодикологично-палеографски сьпоставителни изследвания не са правени, выпросът не може да се смята категорично разрешен и очертава комплексни изследователски перспективи. На този въпрос тук няма да се спираме отделно. Ръкописът от румънското книгохранилище е снабден с множество приписки, а според една от тях става ясно, че най-вероятно преводът на Bтората книга на ПД е извършен на Атон (GAGOVA 2010: 136; CIBRANSKAKOSTOVA 2017).

Обект на нашия интерес в тази статия ще бъдат извадките от ПД в така наречения Загребски сборник на Владислав Граматик от 1469 г. (нататък ВГ 1469), ${ }^{3}$ съставен от книжовника в манастира »Св. Богородица« (или »Матейче«) в област Жеглигово, в подножието на планината Скопска Черна гора на север от Скопие, по порька на Димитьр Кантакузин (MOŠIN 1955: 61-67; DANČEV 1969: 41-58; HRISTOVA 1996: 25-48; GRKOVIĆ-MEJDOOR 1993: 23-24; TURILOV 2005: 99-101). Днес ръкописът се съхранява също в Архива на ХАЗУ под сигнатура III a 47 и има обем от 770 листа. Именно в неговия последен шести раздел от разнообразни четива книжовникът е включил части от началото на ПД на листове $739 \mathrm{v}-752 \mathrm{r}$.

Книжовникът от Ново бърдо е забележителна фигура в балканската история и книжнина от XV век и един от всепризнатите ерудити, които обогатяват и развиват културата на енциклопедичните сборници на Славянското средновековие. Славата му на талантлив съставител е безспорна, а ръкописите му с преводни от гръцки и оригинални славянски творби имат толкова значима стойност, колкото най-известното му ори-

2 За одеския ръкопис, който няма да е във фокуса на внимание в настоящата статия, препращаме към наблюденията и цитираната библиография в изследванията на Кл. Иванова и Н. Гагова - IVANOVA 1987: 102-103; GAGOVA 2001: 79-94; GAGOVA 2010: $130-140$.

3 Тъй като два източника се намират в едно и също хранилище в Загреб, избираме това съкращение за удобство и избягване на двусмислие в израза »загребски ръкопис«. 
гинално произведение - Повестта за възстановяването на Рилския манастир и пренасянето на мощите на Иван Рилски от Търново в Рила. Наред с други преписи, тази повест е известна по негов автограф в Рилския панегирик от 1479 г. (HRISTOVA 1996: 88-89, 166-177). Днес творчеството на дяк Владислав наброява седем сигурни сборника автографи, съхранявани в пет различни хранилища в Европа. Четири от сборниците са точно датирани и попадат в периода непосредствено след завземането на Константинопол от османците през 1453 г. Фактите отразяват динамиката на неговия живот, преминал в различни земи, общности, при различни владетели и меценати, но неизменно в служба на книгата. Миграцията на самите ръкописи очертава същата богата географска топика, както и тяхната актуалност за литературните тенденции през XV в. на Балканите. Затова фактьт, че в един от най-богатите по състав негови трудове, какъвто е ВГ 1469, са включени ексцерпти от един друг голям византийски компендиум, какъвто е ПД, не може да бъде случаен. Самият сборник от 1469 г. е открит от архимандрит Иларион Руварац, който го предава на първия му изследовател и популяризатор Дж. Даничич; важна е и една ранна публикация на М. Сперански върху него (DANIČIĆ 1869: 44-85; SPERANSKIJ 1900: 325-338). Обобщено казано, това е най-обемният автограф на Владислав Граматик, с изключително присъствие на догматико-полемичната и антикатолическата линия, богато орнаментиран в балкански плетеничен стил и с обилие от маргинални схолии, вариращи от разсъждения как е възможно Богородица да е имала сестра, при положение че Йоаким и Анна нямат друго дете, до това, какво представляват делфините, мандрагората и т.н. (SPERANSKIJ 1900: 327-328, 333). Към спецификата на сборника спада и поместването единствено в него на извадки от ПД.

Конкретните ни цели в настоящата публикация са да приведем изцяло или с текст проби онези части от $B Г$ 1469, които са необходими за доказване на работната ни теза; да отговорим на въпроса в какви интертекстови връзки се намират тези ексцерпти спрямо запазените славянски преписи от Пд; какви данни за особеностите на славянския превод разкриват; каква информация носят за значението и ролята на ПД в славянския православен свят и как възпроизвеждат различни страни от универсалния модел на средновековното православно общество - симбиозата на политическата власт с книжнината и културата, на владетеля с православието, на светската и духовната власт в борбата с ересите. Именно това прави от ПД не просто книжовно произведение, а уникален исторически и догматически извор и й осигурява обществено-историческа макрорамка за дълготрайно присъствие в различна среда и в различни епохи. Вся- 
ка форма на рецепция на ПД би била ключ за ориентиране в гръцката изворова база, която днес наброява повече от 70 известни преписа на ПД. При това важно обстоятелство е че, съдейки от гръцката писмена традиция след XIV в., т.е. съвременната на славянските ръкописи с ПД и на $B \Gamma$ 1469 , толкова обемен труд, колкото Зигавиновият, вече се е разпространявал по няколко различни начина. На първо място като цялостен текст; също така в две отделни книги, т.е. Първата и Bтората книга на ПД съществуват самостоятелно, и на трето място - като колекции от различни извлечения с преструктуриране на текста и номерацията на титулите, но винаги формата на битуване е била съобразена с нуждите и целите на преписването и използването.

\section{2. АНАЛИЗ НА ЕКСЦЕРПТИТЕ}

Така поставена, вътрешната логика на настоящата статия изисква задължително да се започне с идентификацията на фрагментите от ПД във ВГ 1469 и представянето на самите текстове.

Първата текстова единица е по същество енкомион (най-общо текст

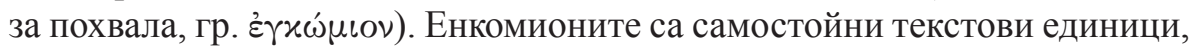
поместени в началото на оригиналната гръцка Паноплия. Известно е, че Евтимий Зигавин е съставил енкомион от 34 реда за своя вдъхновител Алексий I Комнин. В някои гръцки ръкописи той е засвидетелстван с

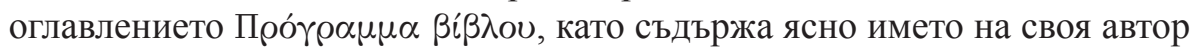
и името на адресата. Именно този енкомион е преписан от Владислав Граматик. На този факт досега не е обрьщано подобаващо внимание, $a$ именно това е първата текстова единица от ПД, която книжовникьт от Ново бърдо е включил в своя сборник, като дори я е оформил на л. 739v със специални сигнални елементи и с типичен завършек във формата на триъгълник, който може да се види и на други места в ръкописа. Същият енкомион се намира на следните фолиа в двата славянски ръкописа с Първата книга на ПД и тяхното съответствие в изданието на грьцката Паноплия: ${ }^{4}$ HM.SMS $1862 \mathrm{r}-2 \mathrm{v}=I I I$ с $161 \mathrm{v}-2 \mathrm{v} ;$ PG 19-20. Оглавлени-

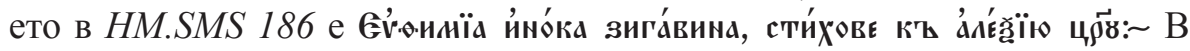
III c 16 е добавено допълнение към идентичното киноварно оглавление

4 В статията се използва изданието на ПД на Жак-Пол Мин от 1865 г. поради липса на ново пълно критическо издание. Изключително полезни са данните за стиховете и Пролога на Паноплията в цитираната книга М. Берке, която обаче е посветена на титули 23-28. Авторката съзнава, че критическо издание на повече грьцки източници би направило изводите за характера на превода в славянската традиция на ПД много по-убедителни. 


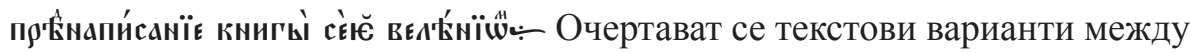
HM.SMS 186 и III с 16, от една страна, и представеното у ВГ 1469. Безспорно става въпрос за един и същ енкомион, но с известни различия при $B Г$ 1469. Затова привеждаме текстовете паралелно. От двата ръкописа HM.SMS 186 и III c 16 приемаме за водещ препис хилендарския. ${ }^{5}$ Придържаме се към неговия правопис изцяло без лигатурите и с тази разлика, че за настоящите цели сегментацията не е организирана ред за ред, а се спазва само сигналното маркиране за нов абзац на нов ред и нова страница.

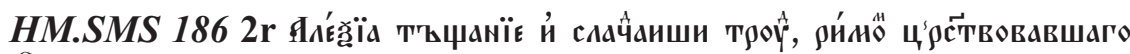

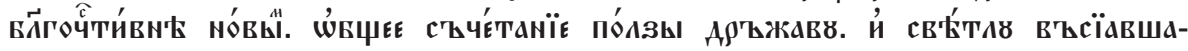

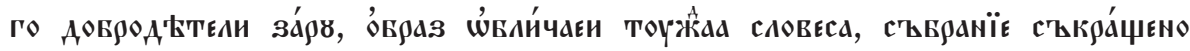

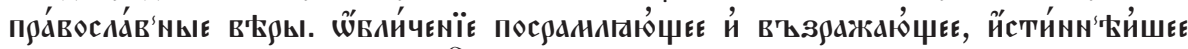

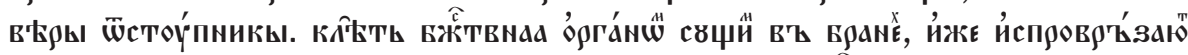

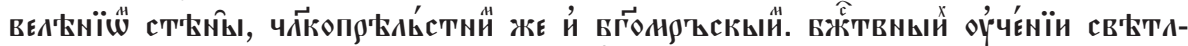

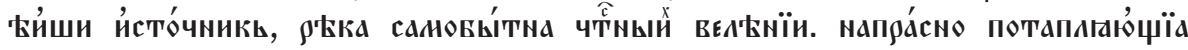

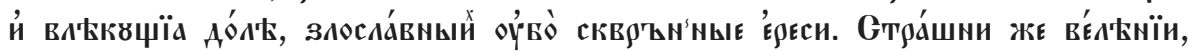

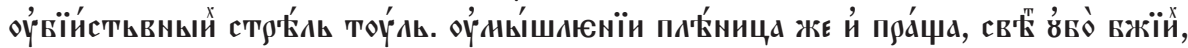

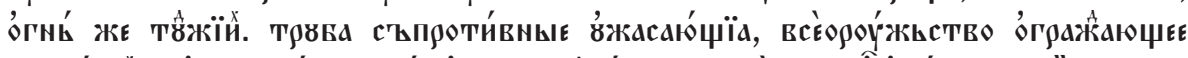

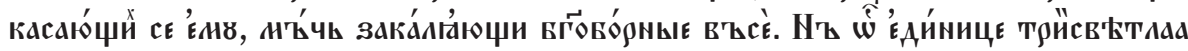

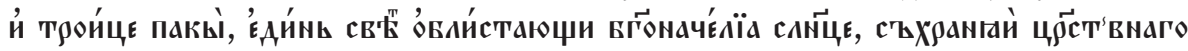

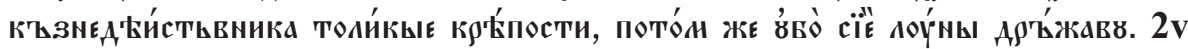

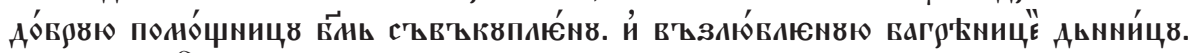

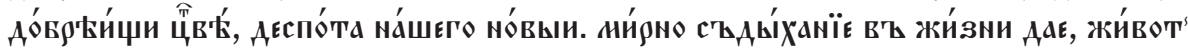

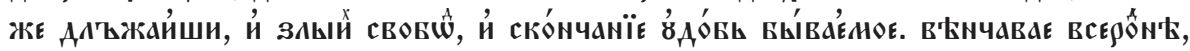

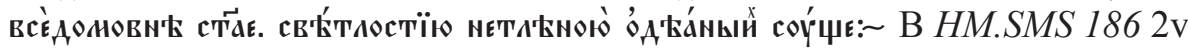
(III c 16 2v; // PG 20) под отделен рубрикатор продължава отново енкомион: То́гоӝв зи́гавйна:

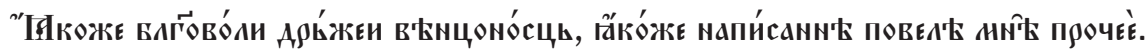

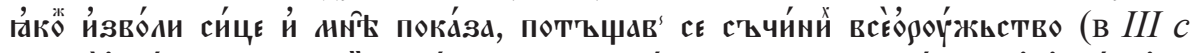

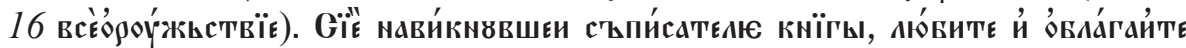

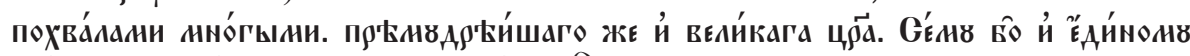

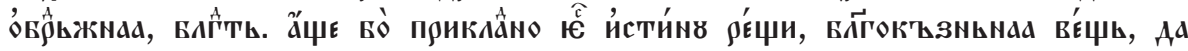
пада"̈ зави́стт: -

5 Дължим специална благодарност на хилендарското монашеско братство заради приносите му за опазване на славянското ръкописно наследство, както и за възможността да ползвам дигиталното копие на ръкописа. Нашата искрена признателност е отправена още към проф. Предраг Матеич и д-р Мери-Альн Джонсън. 


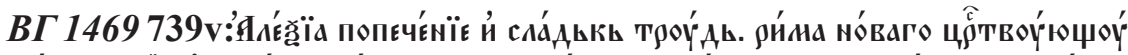

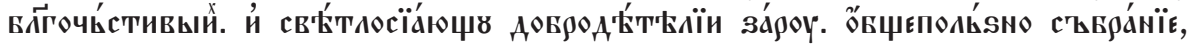

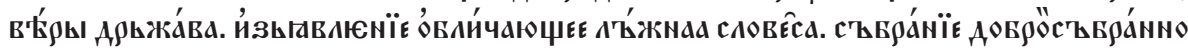

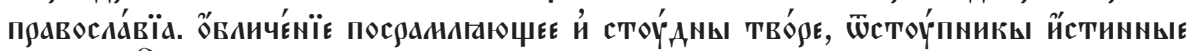

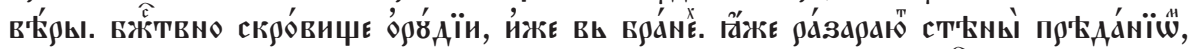

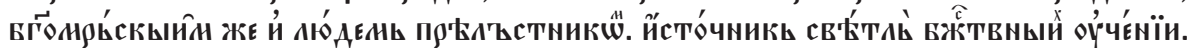

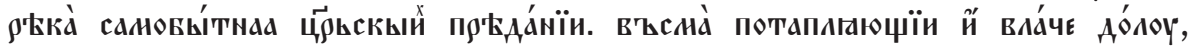

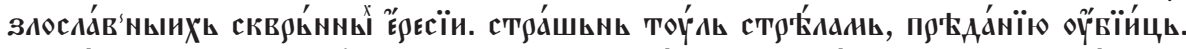

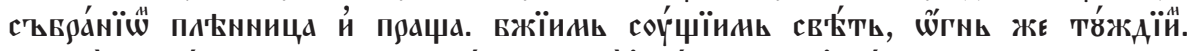

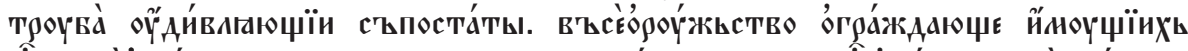

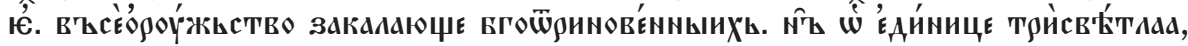

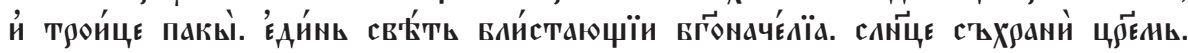

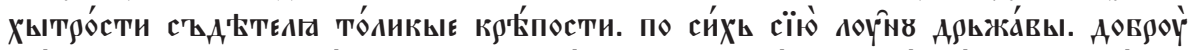

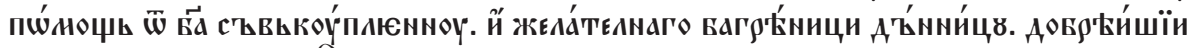

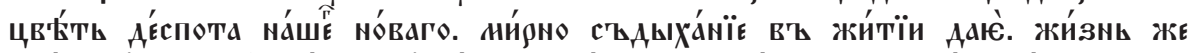

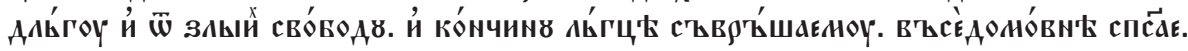

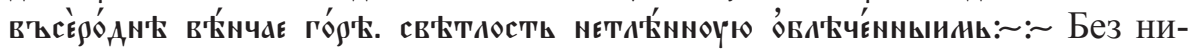
какво прекъсване и оглавление, а само маркиран с киноварен малък ини-

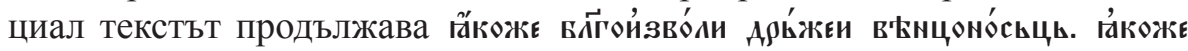

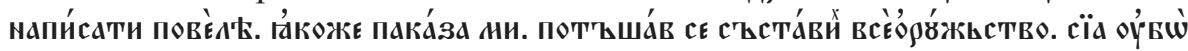

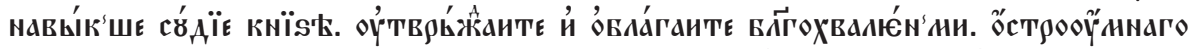

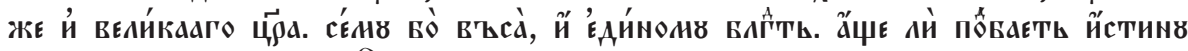

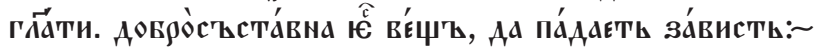

В началото на нашия анализ трябва да отбележим, че за прьв път темата за енкомионите от ПД в славянски превод е поставена от Дж. Трифунович в кратка, но приносна публикация (TRIFUNOVIĆ 1994). Той се спира само на един енкомион, различен от този във ВГ 1469. Става въпрос за стихове на Георги Памфила от началото на Първата книга според двата славянски преписа. В сравнителните източници той заема съответно HM.SMS $1861 \mathrm{r}-2 \mathrm{r}=$ III c 16 1r-1v; PG 18-19 и започва така: Нач'́⿻

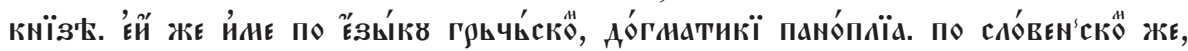

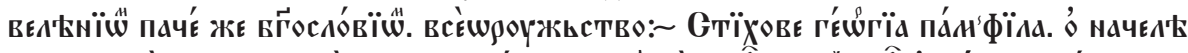

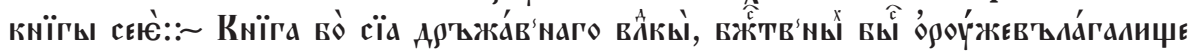
в́́ общите му достойнства за възпроизвеждане на ямбическата стихотворна техника на гръцкия оригинал. В тази публикация преводът се датира от XIII век. Известен с интересите си към средновековната поезия, големият сръбски учен издава така наречения »предговор« на Памфила от 30 стиха на грьцки и славянски, като отбелязва, че метриката не е дословно спазена от преводача. Важни са наблюденията му за езиково-текстово припо- 
криване между двата посочени преписа - HM.SMS 186 и III c 16, откъдето следва, че те възпроизвеждат един и същ превод. Текстовите единици, които имат стойността на енкомиони, обаче, не се изчерпват с издаденото от Дж. Трифунович. Те наброяват общо осем самостойни единици, чието авторство се атрибуира било на самия Евтимий Зигавин, било на споменатия Георги Памфила - спорна личност, за която се предполага, че е

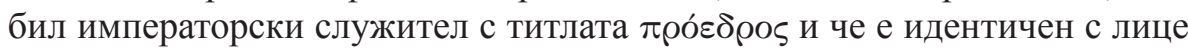
със същото име, за което сведения дават други източници (PARPULOV 2008.a; PARPULOV 2008.b; PARPULOV 2017: 430-431; RIGO 2009: 23). B пълен комплект тези енкомиони се откриват само в двата славянски преписа на Първата книга от ПД. Те възпроизвеждат доста изчерпателно стиховите цялости от най-ранните запазени преписи на гръцката Паноплия. При това текстовете следват традицията на двата емблематични гръцки ръкописа от XII в.: ГИМ Влад. 224 (=Syn.gr. 387) в Москва и Vat. gr. 666 от Ватиканската апостолическа библиотека, които съдържат само Първата книга на ПД и в които текстовете съпътстват серия от миниатюри (SPATHARAKIS 1976: 122-129; FONKICH; POPOV; EVSEEVA 2004 : 13; BERKE 2011: 73-75, 83-84). Ръкописите без всякакво съмнение са създадени за императорския двор. Миниатюрите развиват сюжети, натоварени с дълбоко послание чрез релациите на император Алексий Комнин със светите отци на Църквата и на императора с Христос, на когото той според изображението дори дарява копие от ПД. Само в колофона на московския ръкопис ГИМ Влад. 224 (=Syn.gr. 387), наред с познатите стихове на Зигавин към владетеля, се появяват и стихове, надписани с

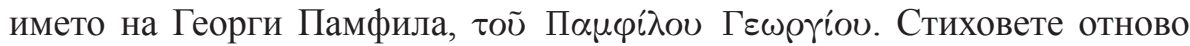
придружават миниатюрите, изобразяващи византийския император в същия ръкопис. Следователно още през XII в. се поставя началото на плодотворната традиция словесни възхвали да се съчетават с иконографски изображения и така да се постига органичното единство на вербални и иконични знаци в изображението на владетеля, така наречените віхо́vєऽ и бті́хо в ПД. Това единство, естествено, не е могло да бъде спазено в славянските преписи, но именно текстовете за похвала са останали като жизнен елемент с тяхното словесно послание.

Що се отнася до поместеното в Загребския сборник на Владислав Граматик, то подборът на точно определен енкомион не е случаен и очевидно съответства на целите на съставителя, на които ще се спрем понататьк.

I. Втората текстова единица от ПД в Загребския сборник на Владислав Граматик е Предисловието на Евтимий Зигавин към кни-

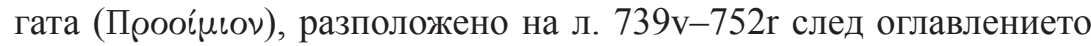


на книгата (DANČEV 1964: 41-58; HRISTOVA 1996: 41). В двата славянски преписа на Първата книга то се намира непосредствено след похвалите (III с 16 3r; HM.SMS $1863 \mathrm{v}$ ). Макар Предисловието да е самостоятелна единица от друг жанров тип, по същество неговото начало е енкомион и също се отнася до ролята на цар Алексий Комнин:

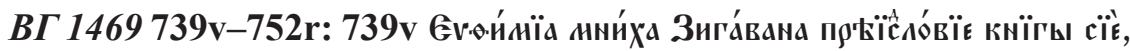

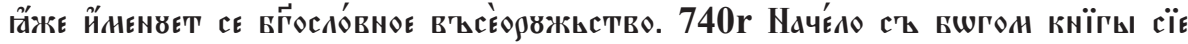

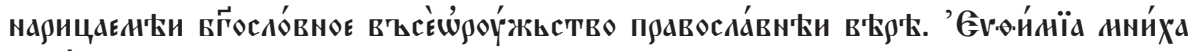
зига́вана: (sic!). Още тук може да се направи изводът, че оглавлението при Владислав Граматик не съвпада с това в HM.SMS 186 и III с 16 и че книжовникът е предпочел вече утвърденото славянско название на книгата. Също така може да се предположи, че той е имал пред себе си препис на ПД, защото според съвременни сравнителни изследвания Предисловието обикновено няма собствено оглавление с много редки изключения. Текстът обаче е трябвало да бъде въведен под някакъв рубрикатор, за да се впише в богатия състав на сборника, чийто съставител е самият Владислав Граматик. Известно е, че в някои грьцки преписи пред име-

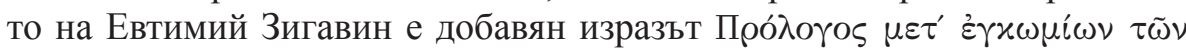
$\pi \rho o ́ \varsigma ~ В \alpha \sigma \iota \lambda \varepsilon ́ \alpha$ и името на императора, откъдето следва, че части от този текст са разпознавани именно като енкомион. Енкомионната част представлява въведението на Предисловието на Зигавин (PG 19-24; BERKE 2011: 33-38). След нея е разположена втората част на Предисловието срещу езичниците елини, епикурейците и други древни философи. В някои гръцки преписи тя се слива с първата глава от Първата книга на ПД. Текстьт у ВГ 1469 е силно редактиран спрямо двата славянски преписа. Тук привеждаме въвеждащата енкомионна част изцяло по ВладиславГраматиковия препис (съответстващ текст в HM.SMS. $1864 \mathrm{r}-5 \mathrm{v}$; същото в III с $163 \mathrm{r}-5 \mathrm{v} / / P G$ 19-24).

\section{ВГ 1469 740r-741r}

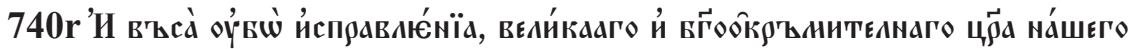
á,

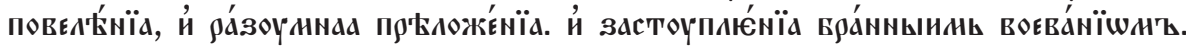

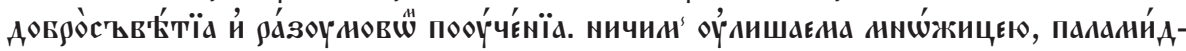

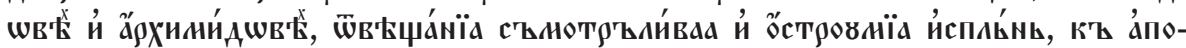

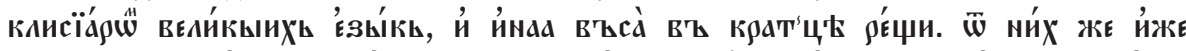

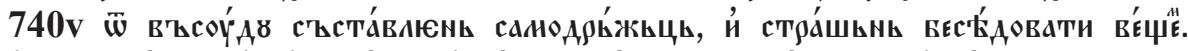

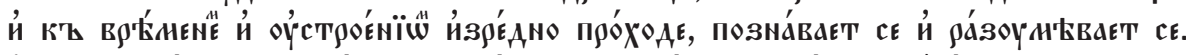

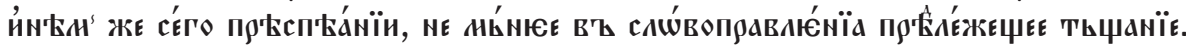




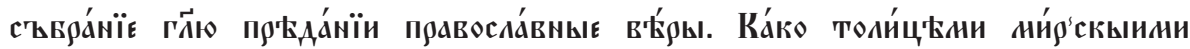

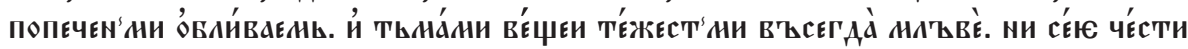

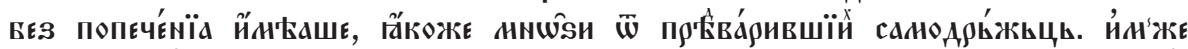

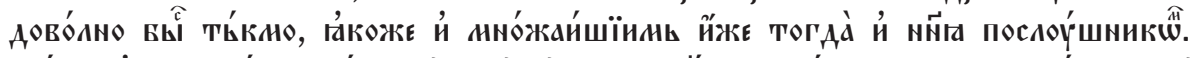

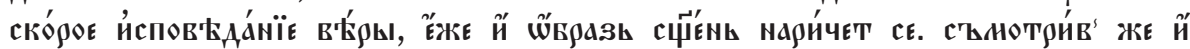

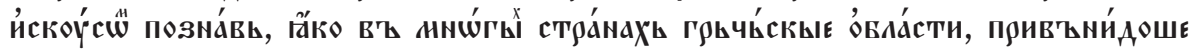

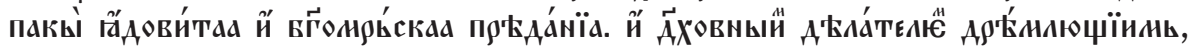

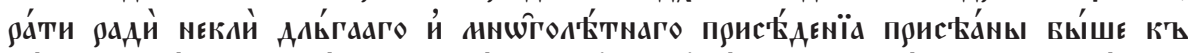

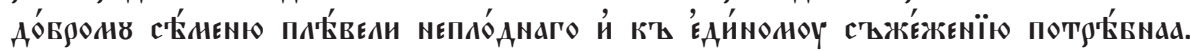

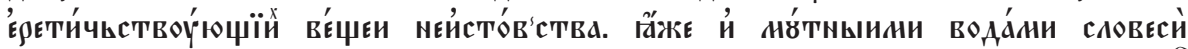

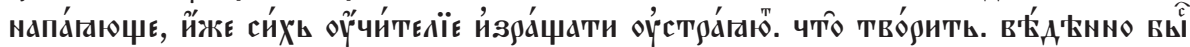

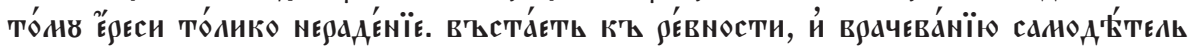

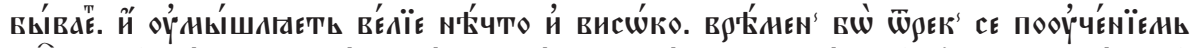

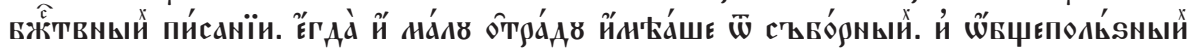

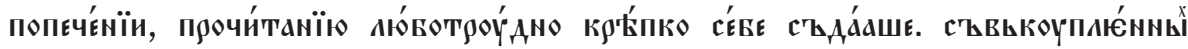

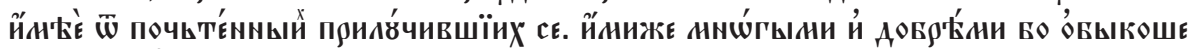

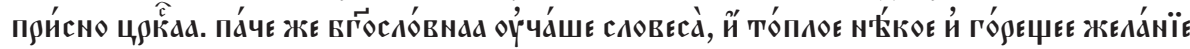

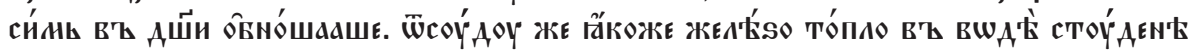

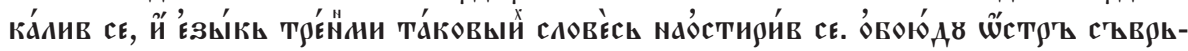

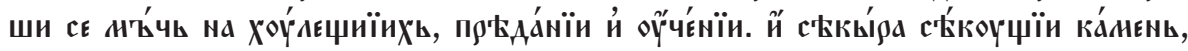

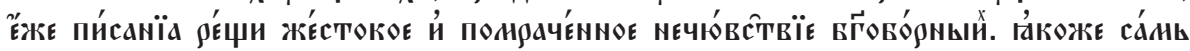

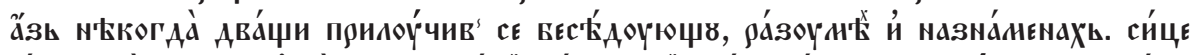

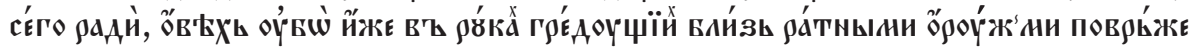

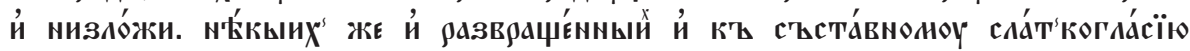

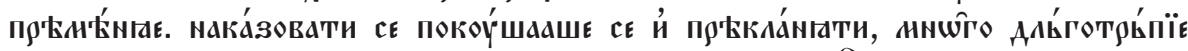

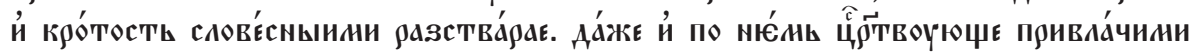

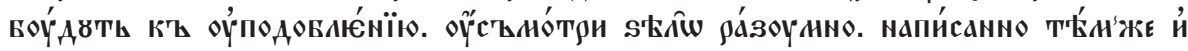

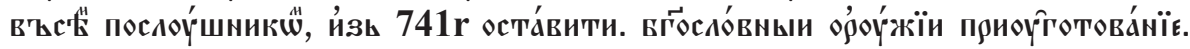

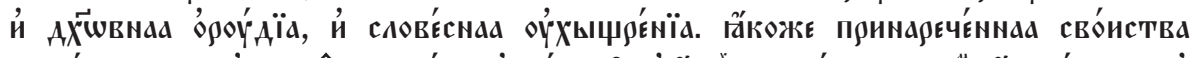

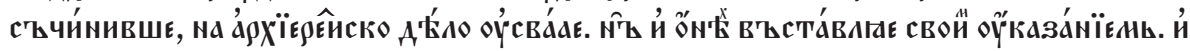

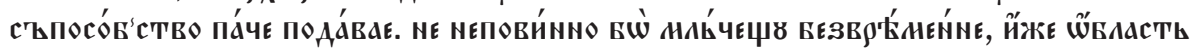

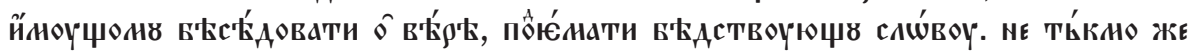

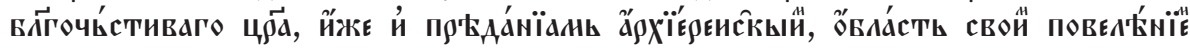

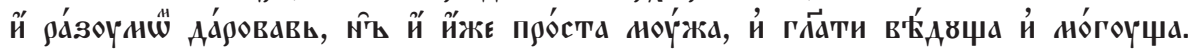

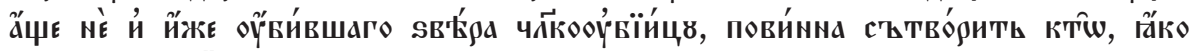

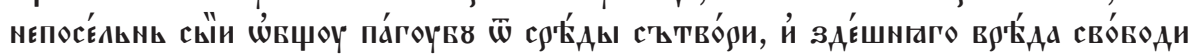

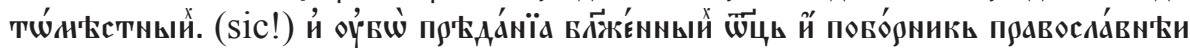
в

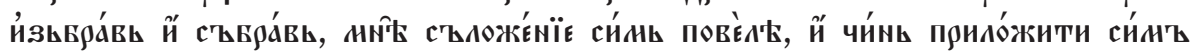

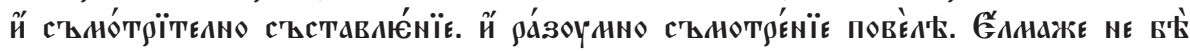




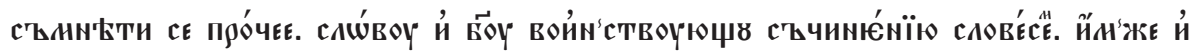

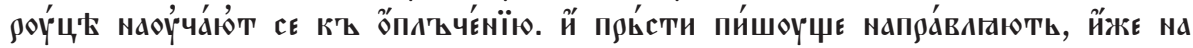
É

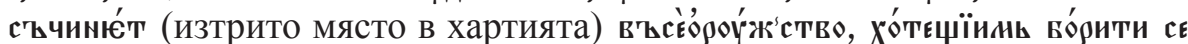

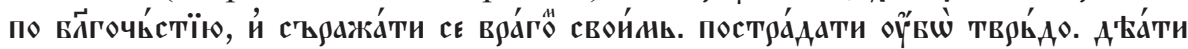

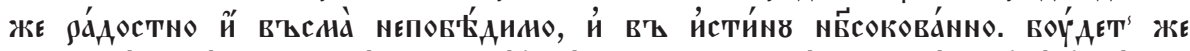

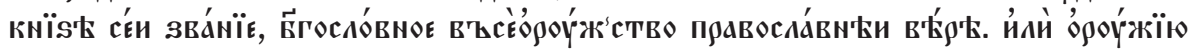

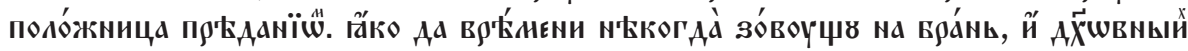

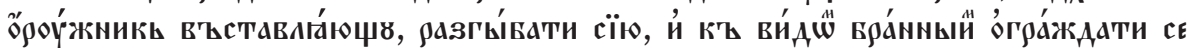

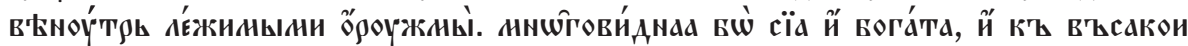
воа́ни довл'ю́щх...

Отдавна е известно, че в своя сборник от 1469 г. Владислав Граматик е поместил Предисловието към ПД. Тази текстова единица се посочва във всички по-важни описания, но интерпретацията защо е включена, обикновено се свежда до обяснението, че най-обемният дял в ръкописа е полемико-догматическият и че макар и да е част от последния разнороден раздел, тя се свързва именно с предходния със своята антиеретическа тема (MOŠIN 1955: 61-67; DANČEV 1969: 56; HRISTOVA 1996: 41). Това безспорно е така, но тук бихме искали да приведем още няколко довода. Смятаме, че и въвеждащият енкомион, и Предисловието от ПД в сборника от 1469 г. са плод на един и същ целенасочен замисъл.

Да започнем с това, че поръчител на сборника от 1469 г. е Димитър Кантакузин - съвременник на Владислав Граматик и лице, свързано с него по силата на конкретните житейски и книжовни обстоятелства. Той не само е наследник на известна византийска династия, но чрез свои родственици има отношение както към родното място на книжовника, Ново бърдо, така и към Жеглиговския манастир »Матейче«, един от големите покровители на който по това време е Мара Бранкович (1416-1487), султанска вдовица и дъщеря на деспот Георги Бранкович от брака му с Ирина Кантакузина (GRKOVIĆ-MEJD̂R 1993: 8-21; 23-27; POPOVIḰ 2014). Нещо повече, така наречената приписка послеслов в сборника от 1469 г., която задава изходните данни на появата му, жанрово се определя като Послание към поръчителя и съдържа редица елементи на възхвала. ${ }^{6}$ Немаловажно допълнение е, че самият Кантакузин е известен с книжовните си занимания и е обичал жанра на похвалата (GRKOVIĆ-MEJD̂R 1993: 15). Оттук между Посланието към Димитьр Кантакузин и началото на ПД в сборника от 1469 г. има пряка тематична връзка. Смята се, че за

6 Издадена в оригинал у DANČEV 1969: 137-142; новобългарски превод у HRISTOVA 1996: 159-164; на съвременен сръбски у GRKOVIĆ-MEJD̂OR 1993: 111-115. 
съставянето на това Послание дяк Владислав е използвал византийски образци и че е заимствал от един друг послеслов, този на дяк Димитър от Кратово към неговия препис на Синтагмата на Матей Властар от 1466 г., изготвен по поръка на висш архиерей (CIBRANSKA 1995: 91-98). Послесловьт в Загребския сборник от 1469 г. дава да се разбере, че Кантакузин е дал своите нареждания в писмен вид и че Владислав Граматик е имал предварително събрани съчинения и готови списъци с други, които е ползвал при съставителството. Затова едва ли ще сме далеч от истината, ако предположим, че и двамата книжовници са били запознати с наличието на славянски преписи на ПД, че са оценявали »православната енциклопедия « на Зигавин и че в един, по същество славянски енциклопедичен сборник, от нея целенасочено са били подбрани именно енкомиони, които възпроизвеждат парадигмата на властта чрез устойчиви идеи и формули. Същите или подобни възхваляващи елементи откриваме в Посланието на Владислав Граматик към Димитьр Кантакузин. Ето някои от тях.

На първо място, титулатурното обрьщение господаль към поръчителя създава йерархия между книжовника и адресата, или така нареченото статусно неравенство, официалност, висок регистър на стила. В това поле Се откроява титулатурата твою Благоплєм'Енствиє, която насочва към благородния произход на адресата, без да указва конкретна титла или дльжност, тъй като и до днес за Димитър Кантакузин в този аспект не се знае нищо категорично. Известно е, че за социалния статус на Кантакузин са изказвани различни предположения, вариращи от наследник на професията на своя баща, т.е. митнически чиновник в Ново Бърдо, през търговец, знатен рудар или управител на имоти на Мара Бранкович, до господар на териториално владение, в обсега на което е влизал и Жеглиговският манастир (DANČEV 1969: 35-37). На второ място, качествата на господаря са обект на словесни възхвали с трафаретни епитети и субстантиви, в които най-високо е поставено благочестието в Христа. Кантакузин е ръководен в благодатта от св. Дух и Троицата, той е православен и защитник на православието, преблагочестив, почитаем, светъл, мъдър, обхванат е от стремеж към познание, а вярата и знанието му са »като медни пити в духовното съкровище на неговото сърце« и чрез тях »като в огледало« той дава напътствия на книжовника (примери

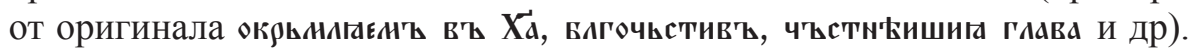
Анализът на всички езикови структури не е непосредствена наша задача тук, но Посланието заслужава обстоен лингвистичен коментар. То е ехо от традициите на енкомиона към владетеля и неговия семиотичен код с архетипове и идеологеми на властта, в които вербалната знакова система 
създава устойчив владетелски етикет. Енкомионите в ПД също са проява именно на този владетелски етикет и най-важното - те са много подходящи в конкретната ситуация при създаването на ВГ 1469, защото са модел, утвърждаващ ролята на владетеля за укрепването на православието чрез неговото свещено писмено наследство. Приблизително 15 години след падането на Константинопол под османска власт, когато е създаден $B \Gamma$ 1469 , словесната риторика вече не е пряко проявление на господстващата владетелска идеология, но продължава да копира и доразвива византийските модели на властта като ценностна културна парадигма. Християнската книжнина не престава да бъде и дори с нова сила играе роля на идейнооформящ фактор в общественото и културното развитие при новите условия. Тя осигурява консолидирането на християнската общност и непрекъснато, чрез възпроизвеждането на традицията, пресъздава загубеното християнско царство, което вече живее във и чрез Църквата и Писанията.

След като формулирахме нашата хипотеза защо Владислав Граматик е използвал две съставни единици от ПД в своя сборник, нека приведем примерни текст проби как ги е използвал, в каква езикова форма са представени тези ексцерпти. Паралелното публикуване на енкомиона на Зигавин към Алексий Комнин и примерните разночетения в Предисловието убеждават в сериозната редакторска работа на книжовника. Спецификите в лексикално-граматическия облик са много и би следвало да са тема на отделна публикация. Тук ще приведем избрани примери от Предисловието: замяна на лексеми и цели изрази, пропускане или видоизменяне, без по същество да се нарушава смисъльт:

\begin{tabular}{|c|c|c|}
\hline HM.SMS 186 & $B Г 1469$ & $P G$ \\
\hline наро́чита & тавліе́на & $\pi \varepsilon \rho \iota \varphi \alpha \nu \tilde{\eta}$ \\
\hline 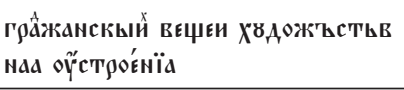 & 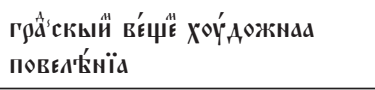 & $\begin{array}{l}\pi 0 \lambda \iota \tau \iota x \omega \tilde{\omega} \nu \pi \rho \alpha \gamma \mu \alpha \dot{\tau} \omega \nu \nu \\
\varepsilon \pi \iota \sigma \tau \eta \mu \nu \iota x \alpha i \quad \delta \iota \alpha \tau \alpha \gamma \alpha i\end{array}$ \\
\hline 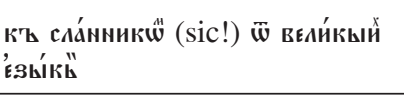 & 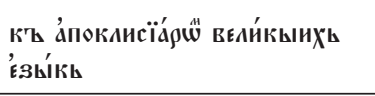 & 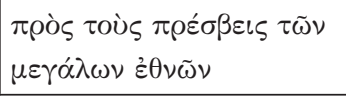 \\
\hline 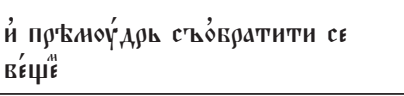 & 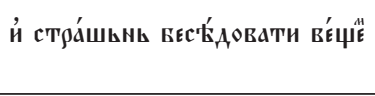 & 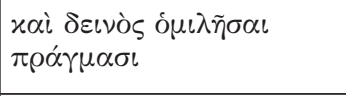 \\
\hline 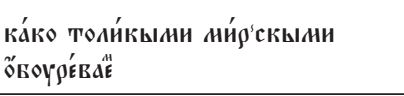 & 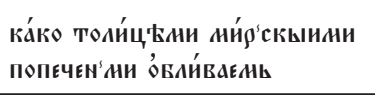 & 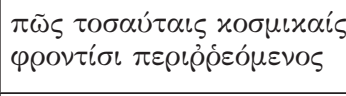 \\
\hline 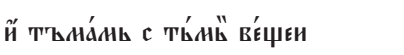 & й ТЬАА́'НИ ве́ЩЕИ & 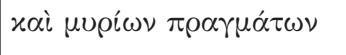 \\
\hline
\end{tabular}




\begin{tabular}{|c|c|c|}
\hline HM.SMS 186 & ВГ 1469 & $P G$ \\
\hline 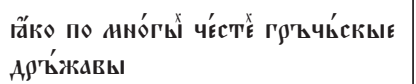 & 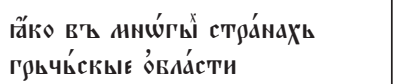 & 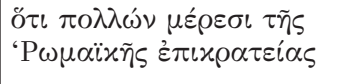 \\
\hline 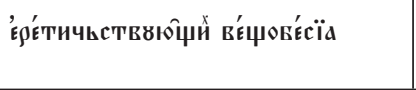 & 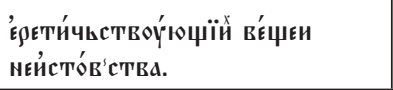 & $\begin{array}{l}\tau \tilde{\omega} \nu \alpha i \rho \varepsilon \tau i \zeta \delta ́ \nu \tau \omega \nu \\
\varepsilon i \delta \omega \lambda o \mu \alpha \nu i \alpha \varsigma\end{array}$ \\
\hline 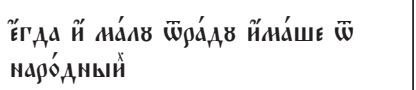 & 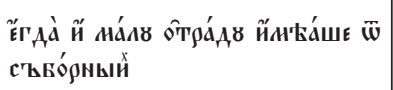 & 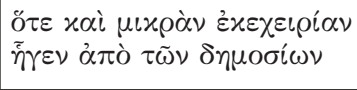 \\
\hline 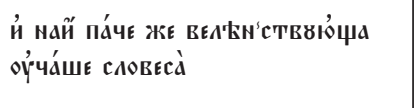 & 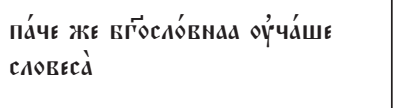 & 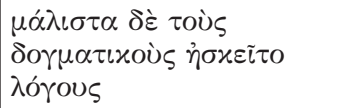 \\
\hline 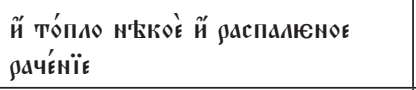 & 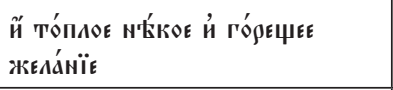 & 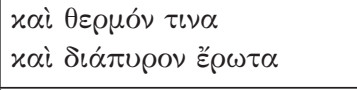 \\
\hline 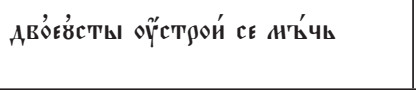 & 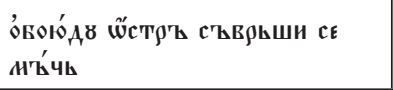 & 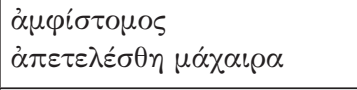 \\
\hline 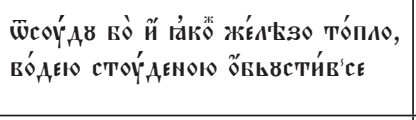 & 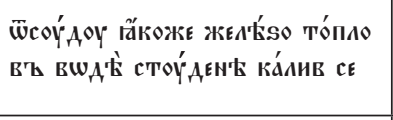 & 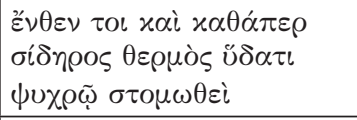 \\
\hline 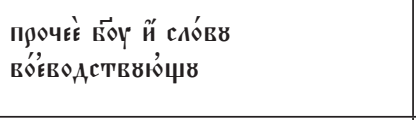 & сли́воу й Боу войнствоуюцв & 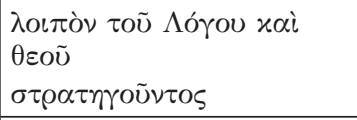 \\
\hline 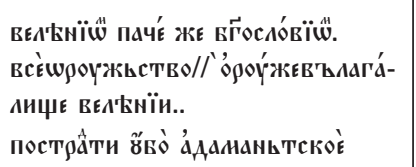 & 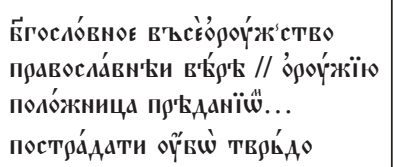 & 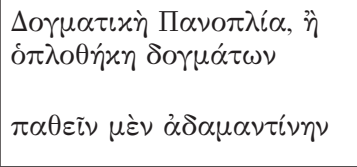 \\
\hline
\end{tabular}

Цялостният сравнителен анализ на ексцерптите от ПД във ВГ 1469 и в двата запазени славянски преписа от Първата книга на ПД ще очертае типологията на разночетенията, които поставят както тясно лингвистични, така и по-широки културно-исторически выпроси, но при всички случаи илюстрират интереса към едно от най-великите съчинения на Средновековието в православния свят с дълготраен живот във времето.

\section{3. ИЗВОДИ}

Следователно в Загребския сборник на Владислав Граматик е налице особена форма на битуване на ПД в славянска среда. Спецификата се изразява в откъсване на две съставни части - енкомиона на Евтимий Зигавин към ияар Алексий Комнин и Предисловието му към ПД, от тяхната естествена среда в Първата книга на ПД и добавянето им в сборник, илюстриращ особената релация между книжовник и поръчител, която, 
имайки предвид биографиите на Владислав Граматик и Димитьр Кантакузин, вероятно е била сьпроводена и с допълнителна релация на един книжовник към друг. Частите от ПД в сборника от 1469 г. са не само обособен текстов комплекс, но са възпроизведени с подобаваща украса на важни самостоятелни четива. В изписването им преписвачът е използвал завидната техника на украсената многоцветна заставка в балкански плетеничен стил, червенословите, малките инициали, знаците за сегментация. Така частите от ПД се вписват пълноценно в »най-богато украсения автограф« на дяк Владислав (HRISTOVA 1996: 47). Наборните текстове от същия сборник в настоящата статия поставят питане от лингвистично естество - защо преписите на дяк Владислав не съвпадат с основните славянски преписи на ПД? Може ли той да е ползвал различен превод? Тези питания са в пряка зависимост от търсенията кога, къде и от кого е направен преводьт на ПД; в какви езикови отношения помежду си се намират славянските преписи на Първата и Bтората книга на ПД - за един и същ или за два различни превода става въпрос; намесено ли е влиянието на по-стар превод от XIII или XIV в. и има ли основания да се предполага неговото съществуване, съответно какви биха били локализацията и атрибуцията му? Известно е, че според едни изследователи, като Кл. Иванова, школата на Патриарх Евтимий и лично българският патриарх имат отношение към ПД, но тезата, че в Житието на Иларион Мъгленски той е използвал някои антиеретически глави от ПД, основно срещу арменците и богомилите, има както привърженици, така и отрицатели (IVANOVA 1987; VOLSKI 2013; MINCZEW 2015: 13-57). Посъвременните изследвания не подкрепят и мнението, че главата срещу богомилите е била преведена по-рано, откъсната от цялостния славянски превод на ПД. От друга страна, датировката на $B A R 296$ и една приписка на л. 2а в ОГНБ 1/108 заплитат в историята на ПД името на сръбския деспот Стефан Лазаревич $(1402-1427)$, чието управление е време на възстановяване на могъществото на сръбската държава, културен и политически разцвет, а в литературата се утвърждават редица модели на властта (TRIFUNOVIĆ 1979: 184, 230-232). Отговорите на всички поставени въпроси ще са толкова по-убедителни, колкото по-скоро започне текстологичното изследване на славянската ПД. На практика това означава да се очертае цялостната писмена история на ПД в славянска среда по всичките четири известни преписа, цялостни и фрагментарни. Това е мащабна задача, която би следвало да се опре на цялата разностранна информация, налична до момента.

В археографското досие на ПД на славянска почва своето заслужено място трябва да заемат ексцерптите от ПД във ВГ 1469. Възможни са три 
основни хипотези. Първата и за нас най-правдоподобната на този етап на проучване - Владислав Граматик е подбрал текстовете от славянски препис на ПД, но не е извършил нов превод, а е редактирал наличния текст, вероятно чрез сверка с някакъв грьцки източник. Известно е, че редактирането и глосирането чрез множество маргинални бележки, тълкувания, допълнения, обяснения са негова »запазена марка« и особеност на творческия му профил. Редакторската му работа проличава дори в преписи на важни оригинални съчинения на българската книжнина. За пример може да се посочи най-старият датиран препис от Житието на Константин Философ-Кирил в същия сборник от 1469 г., който съдьржа уникални текстови различия без аналог в други преписи. Най-вероятно те се дължат на редакторската намеса на самия Владислав Граматик (HRISTOVA 1996: 40).

Втора по-смела, но според нас и по-малко убедителна хипотеза за ексцерптите от ПД във ВГ 1469 би било да се предположи сьществуването на различен превод от запазения в наличните славянски ръкописи, който той е използвал в готов вид. Третата възможност е предположението, че Владислав Граматик сам е извършил нов превод именно на тези въвеждащи части. Едно е сигурно - в средата и третата четвьрт на XV в., в южнославянска среда, ПД се е преписвала активно. Ареальт на най-активно разпространение отново може да се свърже с влиянието на Атон, където със сигурност е направен превод на Bтората книга на ПД именно в началото на XV в. И Загребската Паноплия в ръкопис III с 16, и сборникът на Владислав Граматик от 1469 г. се локализират в зона на силно влияние от Света гора в районите около Кратово, Косово, Морава, земите на север от Скопие. Атонското монашеско братство, неговата ортодоксия и ортопраксия очевидно са двигател за появата и разпространението на ПД, а твърде вероятно самото то е неин основен потребител, имайки предвид обстоятелството, че гръцките преписи на ПД с атонски произход не престават да се умножават след падането на Константинопол под османска власт през 1453 г., когато пред православието стои историческата необходимост да отстоява догматическите основи на своята идентичност.

\section{ИЗТОЧНИЦИТЕ}

ВГ $1469=$ Загребски сборник на Владислав Граматик, 1469 г., Загреб, Архива на Хърватската академия на науките и изкуството, сигн. III а 47.

III c 16 = сръбски препис от Първата книга на Паноплия Догматика, XVI в., Загреб, колекцията на А. Миханович в Архива на Хърватската академия на науките и изкуството, сигн. III с 16. 
HM.SMS 186 = сръбски препис от Първата книга на Паноплия Догматика, XVI в., Хилендарския манастир на Атон, сигн. HM.SMS 186.

$P G \quad=$ ZIGABENOS, E. Panoplia Dogmatica. - MIGNE, J. P. (ed.). Patrologiae cursus completes. Series graeca. T. 130. coll. 9-1359. 1865. Paris: Imprimerie Catholique.

\section{ЛИТЕРАТУРА}

ÂCIMIRSKIJ 1905. = ЯЦИМИРСКИЙ, А. И. 1905. Славянские и русские рукописи румынских библиотек. Санкт-Петербург: Императорской Академии наук С-П. [ÂCIMIRSKIJ, A. I. 1905. Slavânskie i russkie rukopisi rumynskih bibliotek. SanktPeterburg: Imperatorskoj Akademii nauk S-P.]

ANGOLD, M. 2000. Church and Society in Byzantium under the Comneni (1081-1261). Cambridge: Cambridge University Press.

BARMIN 2008. = БАРМИН, А. В. 2008. Евфимий Зигабен. Православная энциклопедия. T. 17. Москва: Церковно-научный центр »Православня Энциклопедия«, 448-450. [BARMIN, A. V. 2008. Evfimij Zigaben. Pravoslavnaâ ènciklopediâ. T. 17. Moskva: Cerkovno-naučnyj centr »Pravoslavnâ Ènciklopediâ«, 448-450.]

BERKE, M. 2011. An annotated edition of Euthymios Zigabenos, Panoplia Dogmatikē. Chapters 23-28. PhD diss. Queen's University of Belfast.

BOGDANOVIĆ 1978. = БОГДАНОВИЋ, Д. 1978. Каталог ћирилских рукописа манастира Хиландара. Београд: САНУ. [BOGDANOVIĆ, D. 1978. Katalog ćirilskih rukopisa manastira Hilandara. Beograd: SANU.]

CIBRANSKA 1995. = ЦИБРАНСКА, М. 1995. Дяк Димитър Кратовски и неговият Номоканон от 1466 г. Palaeobulgarica XIX/ 1: 91-98. [CIBRANSKA, M. 1995. Dâk Dimit"r Kratovski i negoviât Nomokanon ot 1466 g. Palaeobulgarica XIX/ 1: 91-98.]

CIBRANSKA-KOSTOVA 2017. = ЦИБРАНСКА-КОСТОВА, М. 2017. Кратки бележки върху славянския превод на Паноплия Догматика в BAR Ms.slav. 296 и неговия преводач. Palaeobulgarica XLI/ 4: 3-25. [CIBRANSKA-KOSTOVA, M. 2017. Kratki beležki v"rhu slavânskiâ prevod na Panopliâ Dogmatika v BAR Ms.slav. 296 i negoviâ prevodač. Palaeobulgarica XLI/ 4: 3-25.]

DANČEV 1969. = ДАНЧЕВ, Г. 1969. Владислав Граматик. Книжовник и писател. София: Издателство на БАН. [DANČEV, G. 1969. Vladislav Gramatik. Knižovnik $i$ pisatel. Sofiâ: Izdatelstvo na BAN.]

DANIČIĆ, GJ. 1869. Rukopis Vladislava gramatika pisan godine 1469. Starine 1: 44-85.

FONKICH, B. L.; G. V. POPOV; L. M. EVSEEVA. 2004. Mount Athos Treasures in Russia : tenth to seventeenth centuries: from the museums, libraries and archives of Moscow and the Moscow region. Moscow: Severnyĭ palomnik.

GAGOVA 2001. = ГАГОВА, Н. 2001. Един вероятен преводачески автограф от първата четвърт на XV в. (Още веднъж за ранния славянски превод на »Догматическо всеоръжие« на Евтимий Зигавин). Palaeobulgarica XXV/1: 79-94. [GAGOVA, N. 2001. Edin veroâten prevodačeski avtograf ot p"rvata četv"rt na XV v. (Oŝe vedn"ž 
za ranniâ slavânski prevod na »Dogmatičesko vseor"žie« na Evtimij Zigavin). Palaeobulgarica XXV/1: 79-94.]

GAGOVA2009. = ГАГОВА, Н. 2009. Славянските преводи от гръцки език в светлината на контактите между атонските манастири Ватопед, Хилендар и Пантелеймон в XIV - началото на XV в. M. Kuczyńska (ed). Święta Góra Athos w kulturze Europy. Europa w kulturze Athosa. Gniezno: PAN, 79-87. [GAGOVA, N. 2009. Slavânskite prevodi ot gr"cki ezik v svetlinata na kontaktite meždu atonskite manastiri Vatoped, Hilendar i Pantelejmon v XIV - načaloto na XV v. M. Kuczyńska (ed). Święta Góra Athos w kulturze Europy. Europa w kulturze Athosa. Gniezno: PAN, 79-87.]

GAGOVA 2010. = ГАГОВА, Н. 2010. Владетели и книги. Участието на южнославянския владетел в производството и употребата на книги през Средновековието (IX-XV в.): рещепцията на византийския модел. София: ПАМ Пъблишинг. [GAGOVA, N. 2010. Vladeteli i knigi. Učastieto na ûžnoslavânskiâ vladetel v proizvodstvoto i upotrebata na knigi prez Srednovekovieto (IX-XV v.): recepciâta na vizantijskiâ model. Sofiâ: PAM P"blišing.]

GRKOVIĆ-MEJD̂OR 1993. = ГРКОВИЋ-МЕЈџОР, J. 1993. Списи Димитрија Кантакузина и Владислава Граматика. Београд: Просвета, Српска књижевна задруга. [GRKOVIĆ-MEJD̂OR, J. 1993. Spisi Dimitrija Kantakuzina i Vladislava Gramatika. Beograd: Prosveta, Srpska kn̂iževna zadruga.]

HAMILTON, J.; B. HAMILTON. 1998. Christian Dualist Heresies in the Byzantine World c. $650-$ c. 1450 . Manchester: Manchester University Press.

HRISTOVA 1996. = ХРИСТОВА, Б. 1996. Опис на ръкописите на Владислав Граматик. Велико Търново: ПИК. [HRISTOVA, В. 1996. Opis na r"kopisite na Vladislav Gramatik. Veliko T"rnovo: PIK.]

IVANOVA 1987. = ИВАНОВА, К. 1987. О славянском переводе »Паноплии догматики« Евфимия Зигавина. Л. А. Дмитриев (ред.). Исследования по древней и новой литературе. Ленинград: Наука, 101-105. [IVANOVA, K. 1987. O slavânskom perevode »Panoplii dogmatiki« Evfimiâ Zigavina. L. A. Dmitriev (red.). Issledovaniâ po drevnej i novoj literature. Leningrad: Nauka, 101-105.]

MATEJIC, P.; H. THOMAS (eds.). 1992. Manuscripts on Microform of the Hilandar Research Library (The Ohio State University). T. 1. Columbus: Ohio State University.

MILADINOVA, N. 2010. Panoplia Dogmatike - a study on the anti-heretical anthology of Euthimios Zigabenos in the Post-Byzantine Period. Leuven - Budapest: Katholieke Universiteit Leuven, Central European University Budapest.

MINCZEW, G. 2015. Slowiańskie teksty antyherretyckie jako źródlo do poznania herezji dualistycznych na Balkanach. G. Minczew, M. Skowronek, J.-M.Wolski (red.). Sredniowieczne herezje dualistyczne na Bałkanach. Żródła słowianiskie. Łódź: Wydawnictwo Uniwersytetu Lódzkiego, 13-57.

MIRCEA, I. 2005. Répertoire des manuscrits slaves en Roumanie. Auteurs byzantins et slaves. Révision du texte slave P. Bojčeva. Révision du texte français S. Todorova. Sofia: BAN.

MOŠIN, V. 1955. Ćirilski rukopisi Jugoslavenske akademije. I. dio. Opis rukopisa. Zagreb: JAZU. 
PANAITESCU, P. 1959. Manuscrisele slave din Biblioteca Academiei RPR. Vol. 1. Bucureşti: Editura Academiei.

PARPULOV 2008.a. = ПАРПУЛОВ, Г. 2008.а. Первые списки »Догматического всеоружиящ (ГИМ Син. Гр. 387, Vat. Gr. 666). Б. Фонкича (ред.). Палеография и кодикология: 300 лет после Монфокона. Москва: Институт всеобщей истории PAH, 124-127. [PARPULOV, G. 2008.a. Pervye spiski »Dogmatičeskogo vseoružiâ« (GIM Sin. Gr. 387, Vat. Gr. 666). B. Fonkiča (red.). Paleografiâ i kodikologiâ: 300 let posle Monfokona. Moskva: Institut vseobŝej istorii RAN, 124-127.]

PARPUlOV, G. 2008.b. The Presentation Copies of the Panoplia Dogmatica (Moscow, Gos. Ist. Muz., Syn. gr. 387; Vatican, BAV, Vat. gr. 666). Thirty-Fourth Annual Byzantine Studies Conference. Abstracts. New Jersey: Rutgers, the State University of New Jersey, 84-85.

PARPUlOV, G. 2017. Dogmatic Panoply. V. Tsamakda, (ed.). A Companion to Byzantine Illustrated Manuscripts. (Brill's Companion to the Byzantine World, Volume 2). Leiden: Brill, 430-431.

POPOVIḰ 2014. = ПОПОВИЌ, М. 2014. Мара Бранковиќ. Жената меѓу хрстијанскиот и исламскиот културен круг во XV век. Скопје: ARSstudio. [POPOVIḰ, M. 2014. Mara Brankoviḱ. Ženata meǵu hrstijanskiot i islamskiot kulturen krug vo XV vek. Skopje: ARSstudio.]

RIGO, A. 2009. La panoplie dogmatique d'Euthyme Zigabène: les Pères de l'Église, l'empereur et les hérésies du présent. A. Rigo, P. Ermilov (éd.). Byzantine theologians. The systematization of their own doctrine and their perception of foreign doctrines. Roma: Universita degli studi di Roma »Tor Vergata«, 19-32.

SPATHARAKIS, I. 1976. The Portrait in Byzantine Illuminated Manuscripts. Leiden: E. J. Brill.

SPERANSKIJ 1900. = СПЕРAНСКИЙ, М. И. 1900. Загребският ръкопис на Владислава Граматика. Сборник за народни умотворения 16-17: 325-338. [SPERANSKIJ, M. I. 1900. Zagrebskiât r"kopis na Vladislava Gramatika. Sbornik za narodni umotvoreniâ 16-17: 325-338.]

TRIFUNOVIĆ 1979. = ТРИФУНОВИЋ, Ђ. 1979. Десnот Стефан Лазаревић. (Књижевни радови. Књ. 477.) Београд: Српска књижевна задруга. [TRIFUNOVIĆ, Đ. 1979. Despot Stefan Lazarević. (Kn̂iževni radovi. Kn̂. 477.) Beograd: Srpska kn̂iževna zadruga.]

TRIFUNOVIĆ 1994. = ТРИФУНОВИЋ, Ђ. 1994. Превод стихова Георгија Памфила у Паноплији догматики Јевтимија Зигавина. Зборник Матице српске за књижевност и језик XLII/ 1-3: 469-476. [TRIFUNOVIĆ, Đ. 1994. Prevod stihova Georgija Pamfila u Panopliji dogmatiki Jevtimija Zigavina. Zbornik Matice srpske za kniževnost i jezik XLII/ 1-3: 469-476.]

TURILOV 2005. = ТУРИЛОВ, А. 2005. Владислав Граматик. Православная энциклопедия. T. 9. Москва: Церковно-научный центр »Православня Энциклопедия«, 99-101. [TURILOV, A. 2005. Vladislav Gramatik. Pravoslavnaâ ènciklopediâ. T. 9. Moskva: Cerkovno-naučnyj centr »Pravoslavnâ Ėnciklopediâ«, 99-101.] 
VASIL̂EV; GROZDANOVIĆ; J̌OVANOVIĆ 1980. = ВАСИЉЕВ, Л.; М. ГРОЗДАНОВИЋ; Б. ЈОВАНОВИЋ. 1980. Ново датирање српских рукописа у Библиотеци Румунске Академије наука. Археографски прилози 2: 41-69. [VASIL̂EV, L.; M. GROZDANOVIĆ; B. J̌OVANOVIĆ. 1980. Novo datiran̂e srpskih rukopisa u Biblioteci Rumunske Akademije nauka. Arheografski prilozi 2: 41-69.]

VOLSKI 2013. = ВОЛСКИ, Я-М. 2013. Богомилите и светлината на Житието на св. Иларион Мъгленски от патриарх Евтимий Търновски. Palaeobulgarica XXXVII/4: 74 81. [VOLSKI, Â-M. 2013. Bogomilite i svetlinata na Žitieto na sv. Ilarion M"glenski ot patriarh Evtimij T"rnovski. Palaeobulgarica XXXVII/4: 74-81.]

WICKERT, J. 1910. Die Panoplia Dogmatica des Euthymios Zigabenos. Berlin: Schade.

\section{Sažetak \\ Marijana Cibranska-Kostova \\ ODLOMCI IZ PANOPLIE DOGMATIKE U ZAGREBAČKOM ZBORNIKU VLADISLAVA GRAMATIKA IZ 1469. GODINE}

Rad je usredotočen na prijevodne odlomke iz Panoplie Dogmatike Evtimija Zigavina (12. st.) iz zbornika Vladislava Gramatika iz 1469. godine, koji je poznat i kao Zagrebački zbornik (HAZU, III a 47, 740r-752r). Riječ je o dvije tekstovne jedinice: 1. uvodni enkomij, stihovi pohvale imperatoru Aleksiju Komninu (1081. - 1118.), koji je sastavio sam Evtimij Zigavin; 2. predgovor ili prolog, priložen uz Zigavinov rad. Oba se teksta prvi put objavljuju kao cjelina. Autorica iznosi hipotezu o razlozima uključivanja navedenih tekstova u zbornik i o njihovim tekstovnim vezama s odgovarajućim tekstovima u prijepisima potpunoga crkvenoslavenskog prijevoda prve knjige iz Panoplie Dogmatike, točnije: HM.SMS 186 - prijepis iz 16. st. iz Hilandarskog manastira na Atosu te III c 16 - prijepis iz kolekcije A. Mihanovića iz HAZU-a, također iz 16. st. Usporedba navedenih prijepisa potvrđuje stajalište da je Vladislav Gramatik bio dobro upoznat s antiheretičkim Zigavinim kompendijem i namjerno je odabrao upravo takve tekstovne jedinice koje tematiziraju važne vidove univerzalnoga modela srednjovjekovnoga pravoslavnog društva, simbiozu između političke vlasti, književnosti i kulture te između vladara i pravoslavlja. Oba su teksta iz Zagrebačkoga zbornika tematski povezana s osnovnom idejom opsežne bilješke prepisivača Vladislava na kraju rukopisa IIIa 47, poznate i kao Poslanje književnika Dimitru Kantakuzinu, naručitelju zbornika. Drugi zaključak, izveden na temelju jezičnih karakteristika, jest da su oba odlomka iz Panoplie, koje je prepisao Vladislav Gramatik, drugačije redakcije u odnosu na tekstove objavljene u potpunim slavenskim prijepisima $P a$ noplie. Autorica ističe važnost odlomaka u Zagrebačkom zborniku za utvrđivanje zbirke izvora Panoplie Dogmatike u slavenskoj tradiciji, kao i za odgovore na niz diskutabilnih pitanja gdje je, kada i u čijem autorstvu nastao cjelovit slavenski prijevod. Uska veza s ortodoksijom i ortopraksijom atoškoga monaškog bratstva sigurno je bila pokretač dugotrajnoga rasprostranjivanja i prepisivanja ovoga važnog teksta, posebno nakon 1453. godine kada su pravoslavlju, više nego ikada ranije, bili nužni dogmatski temelji oblikovanja identiteta.

Ključne riječi: enkomiji, Panoplia Dogmatika, crkvenoslavenska tradicija, Vladislav Gramatik, Atos 


\section{$\mathrm{S}$ u m m a r y \\ Mariyana Tsibranska-Kostova \\ THE EXCERPTS OF PANOPLIA DOGMATIKE \\ IN VLADISLAV THE GRAMMARIAN'S ZAGREB MISCELLANY OF 1469}

The paper focuses on the translated excerpts from Euthymios Zigabenos's $12^{\text {th }}$ century Panoplia Dogmatike in the Miscellany of Vladislav Gramatik from 1469, known as well as the Zagreb miscellany (HAZU, III a 47, 740r-752r). Those are two textual unities: 1 . The initial encomium (a set of dedicatory verses) written by Zigabenos and addressed to emperor Alexios I Komnenos (1081-1118); 2. The Preface to the treatise of Zigabenos. The two texts are published as a unity for the first time. The author formulates a hypothesis why these texts have been included and what intertextual links are found with the analogous texts of the full Church Slavonic copies of Panoplia Dogmatike, namely: HM.SMS 186 - a $16^{\text {th }}$ century copy from Hilandar monastery; III c 16 - Mihanovich collection in HAZU, also dated from the $16^{\text {th }}$ century. The comparison allowed to sustain that Vladislav Gramatik was well-acquainted with the Byzantine antiheretical compendium and has purposely chosen unities that reproduced important aspects of the universal model of Medieval Orthodox society: the symbiosis of the political power with the literature and the culture of the ruler with Orthodoxy. Both texts from the Zagreb miscellany are thematically bound to the main idea of the final scribe's note at the end of the manuscript III a 47, the so-called Epistle from the writer that Vladislav Gramatik compiled to his patron and commissioner Demetrius Kantakuzinos. Another conclusion, based on linguistic matters is that both excerpts are in edited version and differ from the quoted Church Slavonic copies of Panoplia. The author points out importance of the studied excerpts for the full written record of Panoplia Dogmatike in the Church Slavonic tradition, as well as for the answers to many controversial issues on where, when and by whom the Church Slavonic translation itself was written. The close connection with the Athonite monastic brotherhood, its orthodoxy and orthopraxy surely was the main mover of its long-term use and spread, especially after 1453, when the Orthodoxy, more than ever, needed the dogmatic bases of its identity.

Keywords: encomia, Panoplia Dogmatike, Church Slavonic tradition, Vladislav Gramatik, Mount Athos 